\title{
Possibilities for Utilization of Solar Thermal Energy in Multi-Family Buildings in Latvia
}

\author{
Aivars Zandeckis, Lelde Timma, Dagnija Blumberga, Claudio Rochas, Institute of Energy Systems and Environment, \\ Riga Technical University
}

\begin{abstract}
The paper is focused on analysis of the current situation for the solar thermal system market in Latvia. Solar energy potential and solar thermal market development in Latvia is compared with those in the countries, where solar irradiation is equivalent to that of the Latvian climate.

This research also includes a description of the solar and pellet combisystem installed for a demonstration pilot project; the main parameters of this system are identified and the performance data for the first month of operations is analysed.

An economic analysis for different heat supply scenarios from simulation data and real performance of the system is shown.
\end{abstract}

Keywords - multi-family building, space heating system, solar pellet combisystem, solar thermal energy

\section{INTRODUCTION}

The energy sector plays a vital role in the development of every country. Sustainable energy policy provides a guarantee for stable economic growth and protects the local market from rapid energy price fluctuations.

One of the leading discussions about the energy sector in the European Union is related to energy efficiency in the building sector. The main objectives for reaching declared energy policy in this field are to decrease energy consumption in already existing buildings and to introduce stricter regulations on the construction of new buildings.

The greatest attention in both defined objectives is paid to the integration of renewable energy resources and the increase in efficiency of fossil fuel transformation technologies.

In 2004 heat demand in 25 EU member states (EU-25) was 6100 TWh. In the European Solar Thermal Technology Platform Report on Solar Heating and Cooling for a Sustainable Energy Future in Europe, it is projected that the heat energy demand be reduced by $36 \%$ or to $3930 \mathrm{TWh}$ of heat energy demand until 2030. At the same time, it has been estimated to cover $20 \%$ of heat energy demand in EU-25 with solar thermal energy until year 2030 [1].

In order to reach the stated solar energy coverage by 2030 , research and development projects on the European level have already been launched in the field of solar thermal energy. SOLLET is one of the projects, which is financially supported by the European Commission. The main goal of this project is to explore possible applications of combined solar thermal energy systems for domestic hot water preparation and space heating [2].

The performance parameters for the evaluation and simulation tools of different combisystems were developed in the International Energy Agency's Task 26 framework [3; 4; 5].
A review on the various types of solar thermal collectors and typical applications for heat supply are presented in [6]. Optical, thermal and thermodynamic analyses have been carried out for the collectors and a description of the models used for the performance analysis is provided.

Solar thermal technologies for hot water preparation have been studied by Hossain et.al [7]. However, recent studies show stagnation in the European market of solar water heating systems. At the same time, solar combisystems are becoming a more popular choice for heat supply solutions in buildings [8; 9].

Based on Weiss and Chasapis et. al $[10 ; 11]$, in the year 2001, 340 thousand $\mathrm{m}^{2}$ of the solar thermal collectors for combisystems were installed in eight European countries (Germany, Austria, France, Holland, Switzerland, Sweden, Denmark and Norway). If assumed that on average $15 \mathrm{~m}^{2}$ of the solar collector area are used for one combisystem, about 22600 solar combysistems were installed in 2001.

Methods for the evaluation of the steady state performance of solar collectors are defined by Gordun and Duffie [12; 13]. Recent studies indicate that methods used for steady-state, flat-plate collector performance evaluation cannot give accurate results for performance in transient conditions [14].

Solar collector loop performance is affected by different parameters: weather conditions [15], building envelope conditions, heat load profiles, configuration of control system, etc $[11 ; 8 ; 16]$.

This article analyses the possibility to integrate solar thermal systems into heat supply systems in renovated multifamily buildings in Latvia.

The main target objects for this research are buildings with autonomous heat supply systems and buildings connected to the district heating system. The smallest group of end-users is multi-family houses. Installations of solar thermal energy systems in individual apartments or the disconnection of buildings from the district heating system is not an objective of the research presented in this article.

$74 \%$ or $4512 \mathrm{GWh}$ from all heat energy produced in Latvia was used for household purposes in 2009. Based on survey data from the Latvian Central Statistical Bureau on energy consumption in households, $75 \%$ of natural resources consumed in households were used for space heating $(\mathrm{SH})$ and domestic hot water (DHW) preparation [17].

\section{EVALUATION OF SOLAR THERMAL ENERGY MARKET}

Solar energy potential in Latvia and countries with the same global solar irradiation potential is shown in Fig.1. 
The country averages are connected by the solid line. The minimal and maximal solar irradiation values in each country are shown as dashed lines. The columns represent the range where $90 \%$ of the country's populated areas belong.

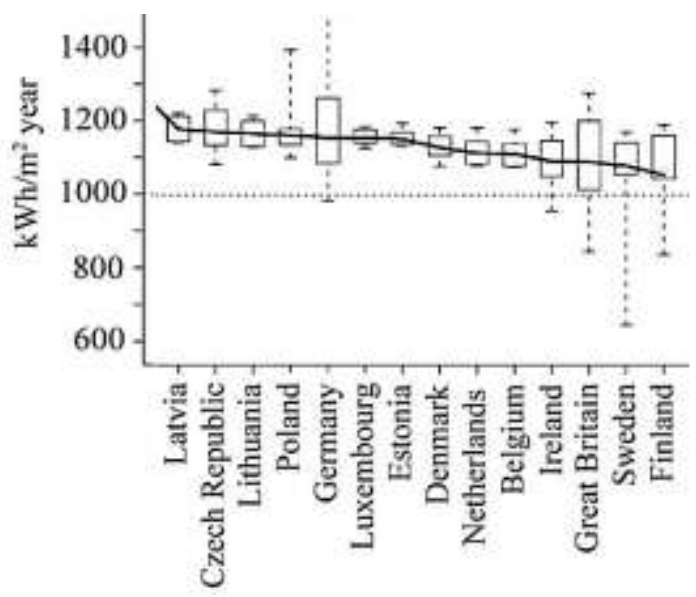

Fig.1. Yearly global irradiation incident on optimally-tilted surface [18]

Yearly global solar energy potential in Latvia is $\sim 1100$ $1200 \mathrm{kWh} / \mathrm{m}^{2}$ year as shown in Fig.1. Latvian average global irradiation is similar to the irradiation levels in such countries as the Czech Republic, Poland, Germany, even Luxembourg and Belgium [18].

Since the average solar thermal potential in Latvia is similar or higher in comparison with countries shown in Fig.1, it is possible to make comparisons on the market size for solar thermal technologies in terms of the collector area per 1000 inhabitants in these countries, see Fig.2.

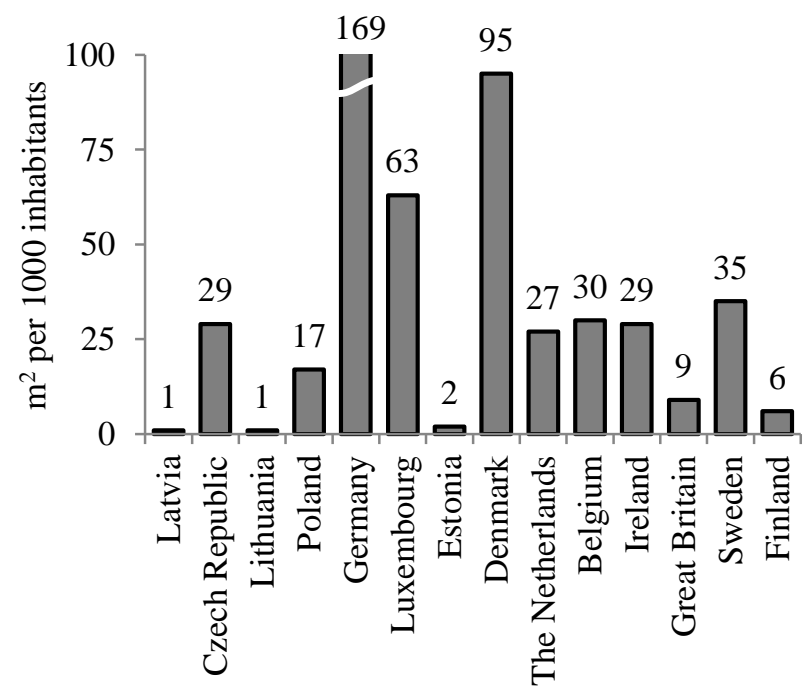

Fig.2. Solar thermal market size in terms of the collector area per 1000 inhabitants in 2010 [19;20].

As stated in the European Solar Thermal Technology Platform [1], different market development in the countries shown in Fig. 2 can be explained by different factors political, public awareness, economical, lobbies, etc. Still, it is needed to be stressed out that the availability of solar thermal technologies is not one of these factors. This means that there are already technological solutions for solar thermal systems available on the market in these countries, which have solar energy potential similar to Latvia.

Research and development are factors, which can force the implementation of solar thermal systems in Latvia. Sweden is a good example. Research in the solar thermal energy field began there in the early 1980s and this led to a situation when this Nordic country has developed one of the highest solar market, in terms of size, in comparison to any other of the countries presented in Fig.2 [21].

Up until 2009, no solar thermal installations for multifamily buildings have been developed in Latvia. Statistical data shows a stagnation in the solar thermal market in Latvia, see Fig. 2 .

Based on the Latvian Central Statistics Bureau, the statistical data on the housing fund in Latvian cities was equal to 39.7 million $\mathrm{m}^{2}$ and public buildings in state's property in the cities - to 6.5 million $\mathrm{m}^{2}$ in 2009 . Therefore, there is a potential that a 40 million $\mathrm{m}^{2}$ of heated area can be utilized for solar thermal energy in Latvian cities [17].

Solar thermal energy market development in Latvia can have the following advantages:

- decrease, in most cases, the consumption of primary fuels;

- flexibility to combine this solution with all types of auxiliary heat supply systems;

- $\quad$ ability to save resources with can be redirected to other sectors;

- $\quad$ lack of significant increase in electricity demand and therefore no need for new installations of electricity supply networks;

- wide availability of solar energy. The common limitations are high latitudes, limited space for heat storage and need for difficult installation constructions;

- $\quad$ ability to accurately calculate operational costs since they are not directly affected by fossil fuel price;

- $\quad$ minimal environmental impact during whole life cycle;

- increase in local employment as solar energy technologies replaces reliance on imported fossil resources [1].

\section{SOLAR COMBISYSTEM PILOT PROJECT DESCRIPTION}

In collaboration with Latvian companies Grandeg, Ltd, VIA - S Ltd, and CC \& R Investments Ltd, Riga Technical University's Institute of Energy Systems and Environment has been working on the project "Compact Solar and Pellet Module", which is supported by the European Union financial instrument. Within the framework of the project, a solar combisystem has been installed in a multi-family building in Latvia.

A. Multi-family house advantages for solar combisystem installation

Studies on possibilities of solar thermal energy utilization for $\mathrm{SH}$ and DHW application in single family homes have been carried out in Latvia. The application of such a system 
for a multi-family house, however, has not been investigated in detail [22].

Nevertheless, a multi-family building possesses some advantages over a single family home in terms of solar energy applicability.

First, a multi-family house has a more uniform heat load profile during the day. This aspect brings out a higher solar energy share without adding additional volume to the accumulation tank. A multi-family house provides a more uniform heat load profile because there are families with small children and seniors, who live in the buildings and consume DHW all day long.

Second, DHW consumption throughout the day presents the possibility to keep lower temperatures in the collectors even during periods of high solar radiation.

Finally, the multi-family house provides a possibility to connect several users to the same combisystem. This means that transformation and transportation losses will be incurred to a lesser extent during the system operation.

\section{B. Description of the pilot project's building}

A solar and pellet combisystem is installed in a multifamily building at $\mathrm{Kr}$. Barona 2 in the city of Sigulda, Latvia.

The pilot project building consists of 4 floors, 30 apartments and 3 staircases, with the total area of $2432.4 \mathrm{~m}^{2}$ and heated area of $1674.9 \mathrm{~m}^{2}$. Clay bricks and concrete panels were used for construction of the external walls of the building. The building has an attic, a basement, and a flat roof.

Before installation of the combisystem, SH and DHW loads in the building were covered by district heating and later - by two autonomous gas boilers. The total nominal capacity of the gas boilers was $198 \mathrm{~kW}$, and they were installed in the basement of the building.

The hot water system was operating with a recirculation loop and two hot water accumulation tanks, with a total volume of 388 litres, each. The space heating system had a distribution system located in the basement. Since balancing of the SH system had not been made, there was an unequal distribution of the SH load in the individual apartments and therefore, the indoor climate temperature was not uniform in all apartments.

During the energy audit performed for the building, it was concluded that the building did not correspond to the current Latvian building code LBN 002-01. The value of the heat loss coefficient of the building envelope reached $2725 \mathrm{~W} / \mathrm{K}$, while the code LBN 002-01 states a maximum permissible value of $1172 \mathrm{~W} / \mathrm{K}$ [23].

The total heat energy consumption of the building was 400 $\mathrm{MWh}$ in 2009, where $240 \mathrm{MWh} /$ year or $144 \mathrm{MWh} / \mathrm{m}^{2}$ year was used for $\mathrm{SH}$ and $160 \mathrm{MWh} /$ year or $96 \mathrm{MWh} / \mathrm{m}^{2}$ year for DHW preparation in the same year [23].

Specific heat energy consumption converted to the degreedays was, on average, $301 \mathrm{MWh} /$ year or $180 \mathrm{kWh} / \mathrm{m}^{2}$ year for $\mathrm{SH}$ and $175 \mathrm{MWh} /$ year or $104 \mathrm{MWh} / \mathrm{m}^{2}$ year for $\mathrm{DHW}$ preparation in the period from the year 2008 to the year 2009 [23].
Calculations and results of the performed energy audit indicated very high DHW consumption $\sim 100 \mathrm{~m}^{3}$ per month. This can be explained by the absence of individual water meters in the apartments. The high SH demand - 180 $\mathrm{MWh} / \mathrm{m}^{2}$ for a standard year is explained by the poor heat resistance of the building envelope.

In order to achieve a higher share of solar energy without oversizing the solar combisystem, a renovation process has begun in the building. The renovation includes: replacement of all SH pipes, installation of a new DHW system with individual water flow meters in each apartment, dismantling towel dryers in the bathrooms, and increase of the thermal resistance of the building envelope with a thermal isolation layer by changing all façade windows and doors in the staircases.

Based on previous research, DHW consumption after the installation of water meters is expected to decrease by $20-50 \%$ [24].

After implementation of the renovation process, the heat energy consumption is expected to be $291 \mathrm{MWh} / \mathrm{year}$, and therefore the combisystem was developed to cover the heat load of the renovated building, see Fig.3.

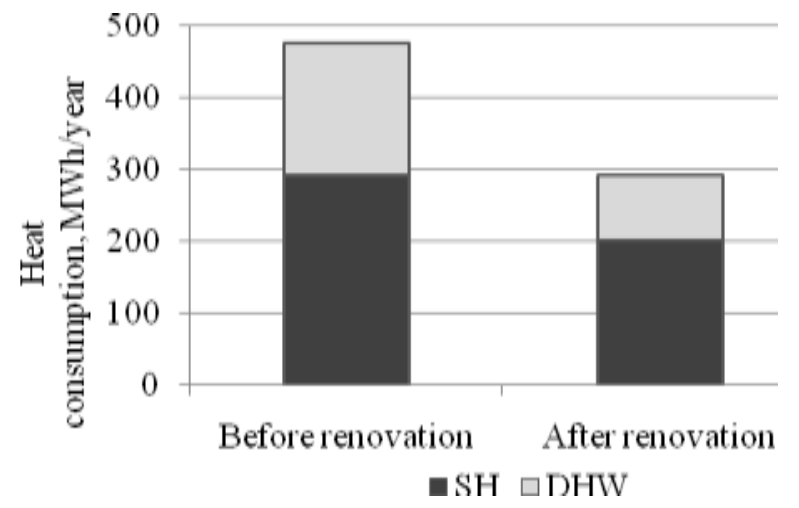

Fig.3. Heat consumption before building renovation (real data) and after building renovation process (assumed data based on energy efficiency measures according to the heat energy audit of the house [23]).

It is planned to decrease heat consumption for $\mathrm{SH}$ by $31 \%$ and DHW by $50 \%$, as shown in Fig.3.

\section{Description of the solar combisystem}

The main idea of the pilot project was to develop a solar combisystem, which occupies as little space as possible and is easy to install. The solution was to develop it in such a way that all the compounds of the combisystem (except solar collectors) are installed in one standard shipping container. The external dimensions of the container are $6000 \times 2900 \times 3100 \mathrm{~mm}$. This solution allows the combisystem to be installed near any multi-family building in a short amount of time.

The shipping container is divided into two parts. The right side of the container is used as pellet storage. The pellet storage has three mounted pellet cones with a $4 \mathrm{~m}^{3}$ internal volume each. It is possible to store up to 7-8 tons of pellets at a time. 
The left part of the container is used for the pellet boiler and accumulation tank installation. All necessary piping for the operation of the system is this section, as well as the heat exchangers, circulation pumps, expansion vessels, monitoring, control systems, etc.

To cover the heat load for the renovated building, 21 flat plate collectors and the pellet boiler were installed.

The floor space of each flat plate collector is $2.03 \mathrm{~m}^{2}$ and an effective area is $1.78 \mathrm{~m}^{2}$. The optical efficiency is equal to 81 $\%$. The collectors are mounted on aluminium frames in three sections, with seven collectors in each section. Collectors are connected in parallel and mounted at latitude $57^{\circ}$, slope $45^{\circ}$ and surface azimuth angle $0^{\circ}$. The heat carrier in the collector loop is a $50 \%$ propylene glycol solution.

A pellet boiler with the nominal capacity of $100 \mathrm{~kW}$ is used. The boiler has an overfeed vertical burner and a vertical flue gas heat exchanger. The boiler can run in three power modes: $35 \mathrm{~kW}, 65 \mathrm{~kW}$ and $100 \mathrm{~kW}$, and is equipped with a burner cleaning system, automatic fuel ignition system, and lambda sensor for air supply control. The boiler has a $50 \mathrm{~kg}$ internal pellet storage tank, which is connected to the main storage unit by an automatic pellet feeding system. The storage unit consists of 3 pellet cones. A screw-type transporter is used for feeding the pellets from the internal storage to the burner. The internal water capacity of the boiler is 219 litres.

The accumulation tank with total volume of $2.35 \mathrm{~m}^{3}$ serves as heat energy storage. It has a $100 \mathrm{~mm}$ thick insulation layer made of mineral wool. The water inlets and outlets inside the tank are located at different heights depending on the input water temperature.

\section{Hydraulic scheme for solar combisystem}

A schematic description of the hydraulic scheme for the solar combisystem is shown in Fig.4. The system consists of 4 main loops: solar collectors, pellet boiler, domestic hot water, and space heating.

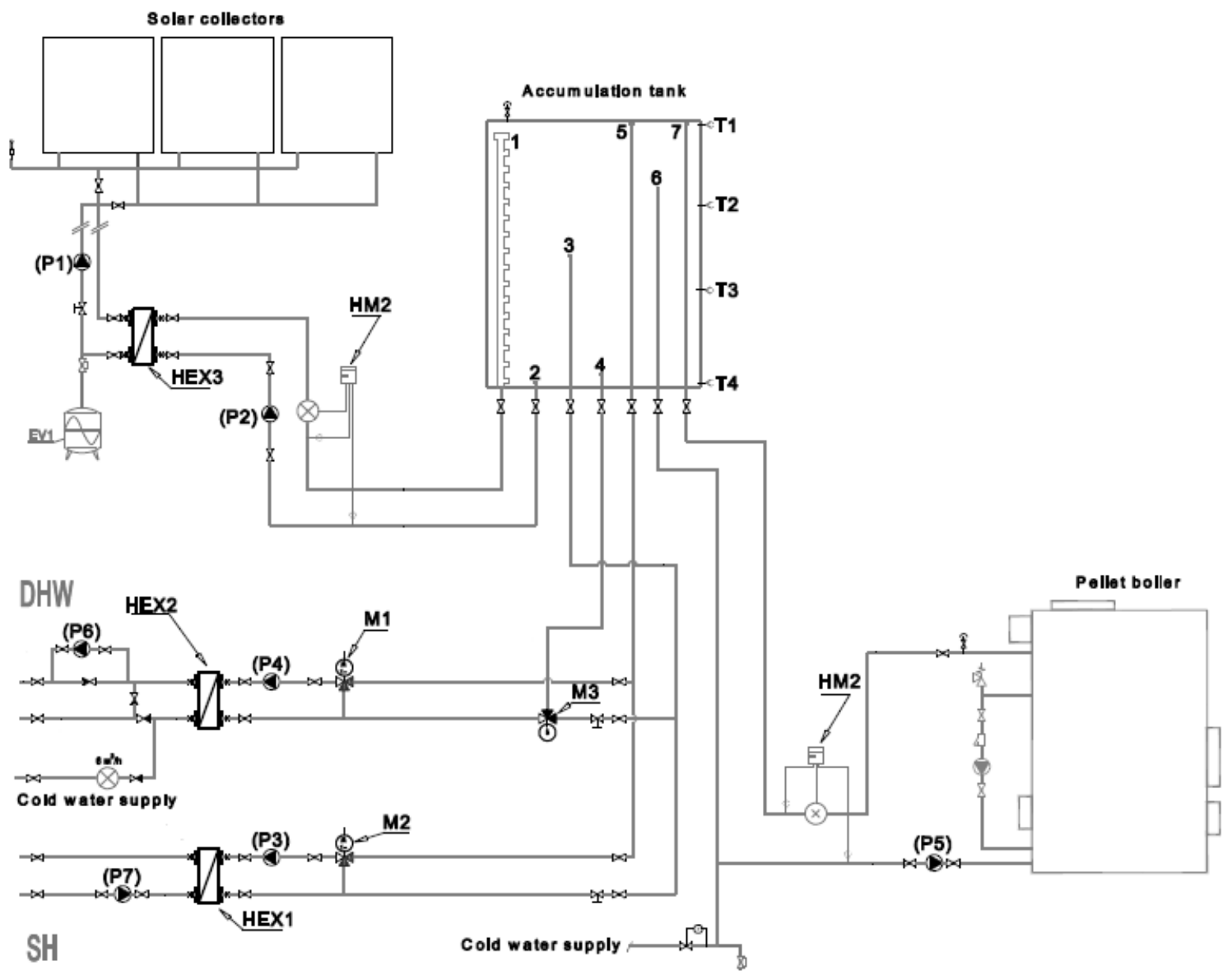

Fig.4. Hydraulic scheme for the solar combisystem.

The accumulation tank can be divided in 4 horizontal sections. The upper part of the accumulation tank is kept at a constant temperature of $65-70{ }^{\circ} \mathrm{C}$. The temperature level is maintained by the pellet boiler. Pipes 6 and 7 are following input and output from the pellet boiler.

The three bottom layers of the accumulation tank are located at variable temperature levels, since they are used to store heat energy produced by the solar collectors. Pipe 2 maintains cool water input to the solar collectors. Inlet 1 corresponds to the stratification column, which prevents water layers of different temperatures from mixing and increases the efficiency of the solar loop.

The remaining pipes 3, 4 and 5 are used for SH and DHW preparation system. Hot water from the accumulation tank is 
fed through pipe 5 to the heat exchangers HEX1 and HEX2, after which the heat energy is supplied to the consumers in the building.

\section{E. Configuration of the solar collector loop}

21 flat plate solar collectors are mounted according to the Tichelmann-ring connection. The application of this kind of connection satisfies the requirement of uniform flow through the collectors. Based on the Tichelmann-ring connection, all collectors are connected in parallel and the total length of the flow and the return feed lines is made equal for each collector [25].

There are 3 parallel series mounted on the roof. They all are connected accordingly to the classic Tichelmann-ring connection. Each of the 3 parallel series has 7 collectors directly linked to meander absorbers in parallel connection.

\section{F. Sensitivity analysis}

Technically it is very difficult to produce all the heat energy required only from solar collectors. Therefore, in order to increase the use of solar thermal energy, heat accumulation systems are introduced. Higher accumulation capacities allow installation of more solar collectors and increase of the solar share in the total energy balance, but also require higher investment costs and more space for installation. In order to have a compact SH and DHW system and to reduce costs of installation, an auxiliary heat supply system is required. In this case a pellet boiler is used, which allows to cover heat load in periods, when solar irradiation is not sufficient.

The share of solar energy in the total energy balance is influenced by solar fraction and the amount of energy produced by the pellet boiler. The solar fraction is influenced by the surface area of the collector, the volume of the heat storage tank, working algorithm of the control units, and other factors.

It is important to note that the heat accumulation tank and the pellet storage unit need to fit in one standard shipping container, therefore an analysis to determine the optimal parameters was carried out.

The volume of the heat accumulation tank was determined by a sensitivity analysis of the following parameters: solar pellet storage size, accumulation tank size, solar collector size and energy costs.

The optimal solution was selected by taking into account not only technical aspects, but also the economic side of the installation, which guarantees that the system will be competitive with other $\mathrm{SH}$ and DHW preparation systems.

The following scenarios of the accumulation tank volume and the collector area were explored:

1) $2.35 \mathrm{~m}^{3}$ storage tank and $40 \mathrm{~m}^{2}$ solar collector;

2) $4.7 \mathrm{~m}^{3}$ storage tank and $80 \mathrm{~m}^{2}$ solar collector;

3) $7.05 \mathrm{~m}^{3}$ storage tank and $120 \mathrm{~m}^{2}$ solar collector;

4) $11 \mathrm{~m}^{3}$ storage tank and $180 \mathrm{~m}^{2}$ solar collector [26].

The following costs are taken into account for each alternative combination:

- $\quad$ price of solar collectors;

- installation costs for the solar collectors;

- $\quad$ pellet price;
- costs of pellet storage tanks (including specific construction required in scenarios with accumulation tanks)

- costs of the heat accumulation tank;

- transportation costs for one load of pellets.

It is assumed that the system's operation time is 20 years.

A more detailed methodology for the calculation of total energy costs is described by Bolonina et al. [26].

Fig.5 represents the results of the performed sensitivity analysis.

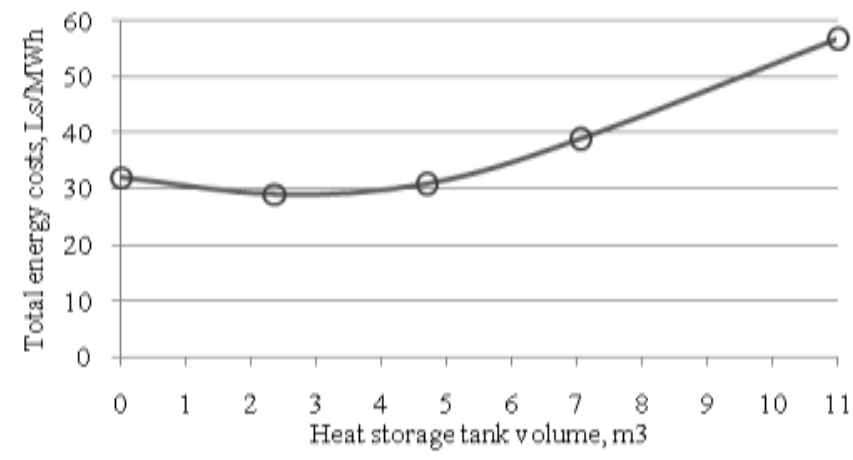

Fig.5. Energy costs based on the combisystem's operational costs [26].

Based on the performed parameters analysis, it was concluded that a smaller solar collector area, in combination with a smaller accumulation tank volume, gives the lowest energy costs due to lower project implementation costs. This combination also allows minimizing operation costs by reducing expenses for pellet transportation.

Based on the calculations for the pilot project site, a solar combisystem with a heat accumulation tank of $2.35 \mathrm{~m}^{3}$ and solar collectors with an effect area of $37.38 \mathrm{~m}^{2}$ has been chosen.

\section{$G$. Theoretical energy saving due to project implementation}

Calculations had been made in order to estimate the project's energy savings and the energy costs of the system after project implementation.

The following assumptions have been made:

- $\quad$ efficiency for natural gas boiler $92 \%$;

- $\quad$ efficiency for biomass boiler $85 \%$;

- $\quad$ specific heat of combustion for natural gas 9.3 MWh/ $1000 \mathrm{~nm}^{3}$;

- $\quad$ specific heat of combustion for pellets $4.8 \mathrm{MWh} / 1000$ $\mathrm{kg}$;

- natural gas price $269.18 \mathrm{LVL} / 1000 \mathrm{~nm}^{3}$ (as for consumers in range from $25000 \mathrm{~nm}^{3} /$ year to 126000 $\mathrm{nm}^{3} /$ year from $1^{\text {st }}$ August 2011) [27];

- $\quad$ price for pellets $110 \mathrm{LVL} / \mathrm{t}$;

- $\quad$ produced solar thermal energy based on simulation data - 19.6 MWh/year.

Three scenarios have been estimated. Each of the scenarios is described in terms of energy consumption and energy costs (see Table I). 
As it can be seen from Table I, even in scenario B, when a renovation project has not been implemented in the building, the savings for energy resources can reach 3000 LVL per year.

By implementation the scenario $\mathrm{C}$, it is planned to reduce heat consumption in the building by $39 \%$ and energy resource savings will account for more than $8000 \mathrm{LVL}$ per year in comparison to scenario A (the reference building).

If one considers that the natural gas price continues to increase, the savings will be even larger.

TABLE I

HEAT SUPPLY SCENARIOS IN TERMS OF ENERGY COSTS

\begin{tabular}{|c|c|c|c|c|}
\hline \multirow{2}{*}{ Heat supply scenario } & \multirow{2}{*}{$\begin{array}{l}\text { Heat consumption } \\
\text { in the building, } \\
\text { MWh/year }\end{array}$} & \multicolumn{3}{|c|}{ Resource consumption for heat supply } \\
\hline & & Type & Quantity & Energy costs, LVL/year \\
\hline $\begin{array}{l}\text { A. Renovation project has not been } \\
\text { implemented in the building and old heat } \\
\text { supply system is used (gas boilers); }\end{array}$ & 476 & Natural gas & $56 \mathrm{t} \mathrm{nm}^{3} /$ year & $\sim 15000$ \\
\hline $\begin{array}{l}\text { B. Renovation project has not been } \\
\text { implemented in the building but old heat } \\
\text { supply system is replaced with the solar } \\
\text { combisystem; }\end{array}$ & 476 & Solar thermal energy and pellets & 112 t/year & $\sim 12000$ \\
\hline $\begin{array}{l}\text { C. Renovation project has been } \\
\text { implemented in the building and old heat } \\
\text { supply system is replaced with the solar } \\
\text { combisystem. }\end{array}$ & 291 & Solar thermal energy and pellets & $67 \mathrm{t} /$ year & $\sim 7000$ \\
\hline
\end{tabular}

\section{PERFORMANCE RESULTS OF THE COMBISYSTEM}

Monitoring of the systems performance has been carried out at the pilot project site. Data has been accumulated for 5 months as described in the following paragraphs.

The total heat energy produced by the combisystem during 5 months is shown in Fig.6.

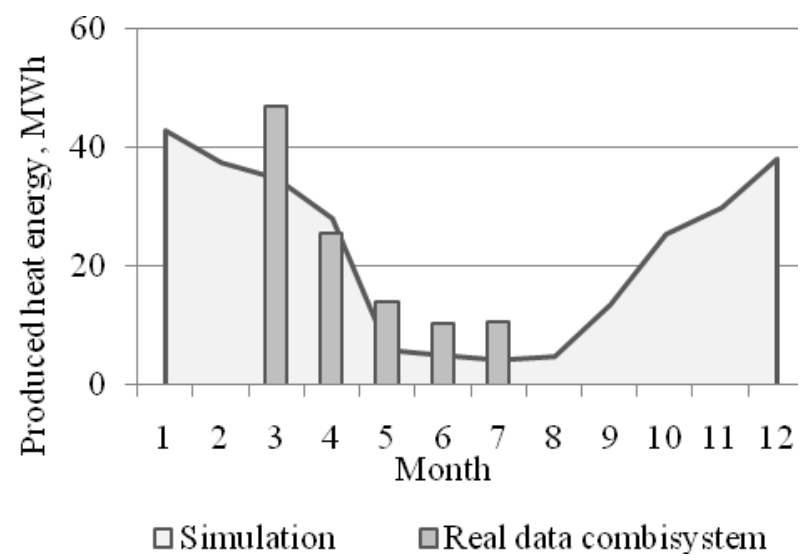

Fig.6. Simulation results and real heat supply system performance at the pilot project site.

Fig.6. shows the difference between the simulated and real heat load profiles. The reason for higher real heat demand in comparison with the simulation results is explained by a delay in the building renovation process.

The reduction of heat demand in the summer period will be achieved by the installation of a new DHW system with individual water meters for each flat. It is anticipated that the implementation of this efficiency measure will achieve a $50 \%$ reduction of heat energy demand for hot water preparation.
The above mentioned reasons have led to the situation when, in the summer months, the heat load of the building was higher than simulated.

\section{A. Solar thermal energy output}

The amount of produced solar thermal energy has also been simulated and then compared with the real solar loop's energy output, see Fig.7.

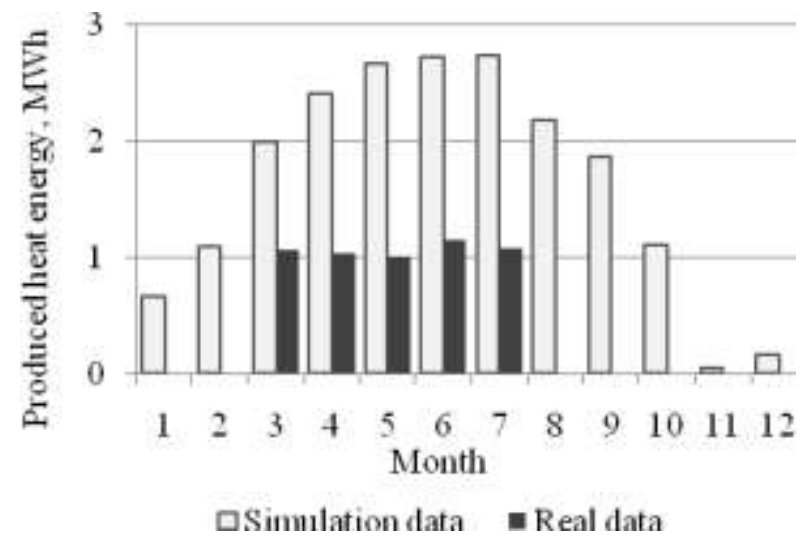

Fig.7. Simulation results and real performance for solar collectors.

Real data shows that the solar collectors loop is not working optimally and the produced heat energy is less then simulated (as shown in Fig.7). The produced heat energy in March was $46 \%$ lower than simulated and in May it was lower than up to $62 \%$.

\section{B. Solar thermal energy share}

Solar thermal energy share can be calculated as produced heat energy by solar collectors referred to the total heat energy produced by the heat supply system at the same time span, see Eq. (1). 


$$
S_{s}=\sum_{i=1}^{n} \frac{Q_{s_{i}}}{Q_{t_{i}}}=\sum_{i=1}^{n} \frac{Q_{s_{i}}}{Q_{s_{i}}+Q_{a_{i}}}
$$

where:

$S_{s}-$ solar thermal energy share, $\%$;

$Q_{t}-$ total energy output from heat supply system;

$Q_{s}-$ energyoutput from solar collectors;

$Q_{a}-$ energy output from auxiliary heat supply system.

As seen from Eq.(1), the fraction of the solar energy share is influenced by two main parameters - energy output from the solar collectors and energy output from the auxiliary heat supply system.

Dependence of the solar energy share from the solar collector energy output is illustrated in Fig.8.

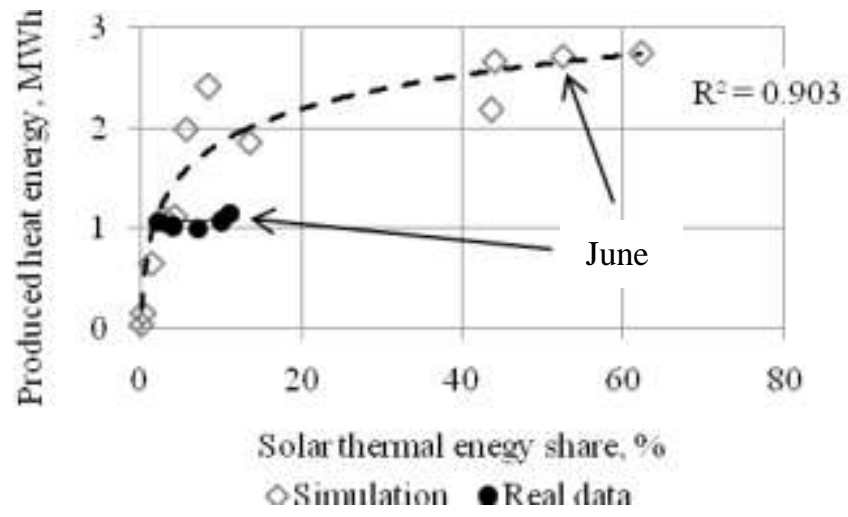

Fig.8. Solar thermal energy share as a function of heat energy output from solar collectors.

Based on the simulation data, the solar thermal energy share corresponds to the logarithmic function with the correlation coefficient value of $90.32 \%$, see Fig.8. Real solar loop heat energy output does not correspond to the simulated curve, because the on-site produced heat energy amount from the solar loop was lower than the simulated one, as shown in Fig.7. The less heat energy output solar collectors give, the smaller share of solar energy is gained.

Solar thermal energy share on-site in June was not close to $60 \%$ not only because solar collectors did not provide simulated heat energy output, but also because of the delay in building's renovation process. Since the renovation process was only started at the end of the summer, the overall buildings heat demand was higher than simulated, as previously shown in Fig.6. Increased heat demand leads to higher usage of the auxiliary heat supply system, which also affected solar thermal energy share, see Fig.9.

In this case, the strength of the simulation curve for the exponential function is obtained as $97.23 \%$, see Fig.9. Data points for the real solar thermal energy share show higher auxiliary heat supply system output, which leads to a decrease in the solar thermal energy share.
It can be concluded that the solar thermal share is equally affected by the performance of the solar loop, the auxiliary heat supply system, as well as by the heat demand in the building. In this case, the influence of all of these factors mentioned results in a low solar thermal energy share.

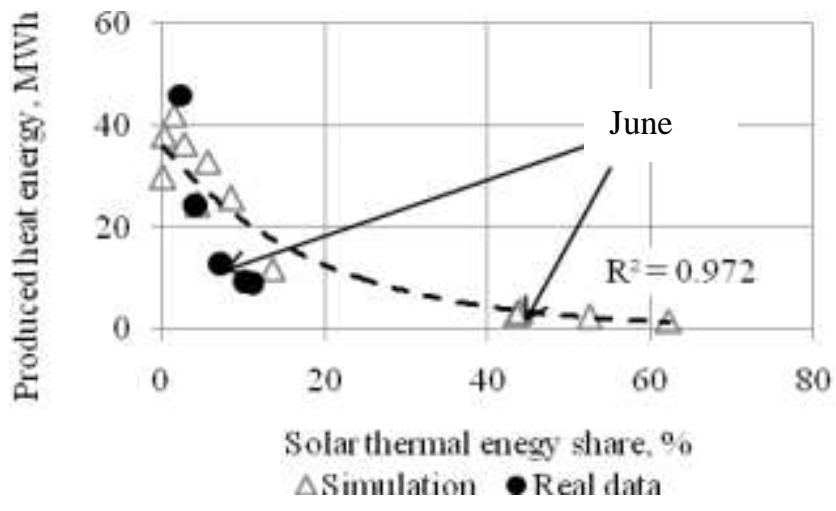

Fig.9. Solar thermal energy share as a function of heat energy output from auxiliary heat supply system.

\section{Real savings resulting from systems performance}

The heat energy demand for previously analyzed five months is known. It is possible to evaluate real savings based on the system's energy costs.

The following assumptions have been made:

- efficiency of the natural gas boiler $92 \%$;

- $\quad$ efficiency of the biomass boiler $85 \%$;

- $\quad$ specific heat of combustion for natural gas 9.3 MWh/ $1000 \mathrm{~nm}^{3}$;

- heat of combustion for pellets is taken from the onsite measurements;

- natural gas price 269.18 LVL/1000 $\mathrm{nm}^{3}$ (as for consumers in range from $25000 \mathrm{~nm}^{3} /$ year to $126000 \mathrm{~nm}^{3} /$ year from 1 August 2011) [27];

- $\quad$ price for pellets are taken from pellet's providers for pilotproject site $(116 \mathrm{LVL} / \mathrm{t})$;

- $\quad$ produced solar thermal energy is $5.33 \mathrm{MWh}$ in 5 months.

All calculations are made for the observed non-renovated building heat demand for the time period from March until July 2011.

Two scenarios are considered - the heat supply system has not been changed in the building, and real data for costs of the combisystem.

Data provided in Table II illustrates real performance for the solar combisystem during the first five months. As it can be seen, even in a non-renovated building, it is economically feasible to use solar thermal energy and pellets for heat supply instead of natural gas. Nevertheless, energy savings will increase by the optimization of the performance of the solar combisystem. 
TABLE II

ENERGY COSTS BASED ON THE REAL PERFORMANCE OF THE COMBISYSTEM

\begin{tabular}{|l|c|c|c|c|}
\hline \multirow{2}{*}{ Heat supply scenario } & \multirow{2}{*}{$\begin{array}{c}\text { Heat consumption in the } \\
\text { building, MWh/5 months }\end{array}$} & Type & Nesources consumption for heat supply \\
\cline { 3 - 5 } & & 108 & $13 \mathrm{tnm}^{3}$ & \multicolumn{2}{c|}{$\begin{array}{c}\text { Quantity } \\
\text { months }\end{array}$} \\
\hline $\begin{array}{l}\text { A. Building heat load is covered with } \\
\text { gas boilers }\end{array}$ & 108 & Solar thermal energy and pellets & $25 \mathrm{t}$ & 3400 \\
\hline $\begin{array}{l}\text { B. Real performance data for the } \\
\text { combisystem }\end{array}$ & & & 3000 \\
\hline
\end{tabular}

\section{IDENTIFIED ERRORS AND FUTURE WORK}

Observations and data analysis were carried out in order to identify reasons for the insufficient performance of solar the combisystem that leads to a lower heat energy output from solar collectors loop than simulated.

Low system performance is partly explained by human factors: poor internal communication between plumbers and installers of the equipment, and absence of experience in work with solar combisystems.

One of the main reasons for insufficient solar loop performance is too high temperature level at the accumulation tank bottom. Since water input for the solar collectors loop is taken exactly from the accumulation tank bottom, this means higher working fluid temperature input for solar collectors, higher heat loss, and lower efficiency.

The solution on how to reach lower water temperature at the bottom of the tank is to use cold water inlet to the hot water preparation exchanger. The temperature for the cold water input is $8-10^{\circ} \mathrm{C}$ throughout the year. Theoretically, this would allow reaching $15-20^{\circ} \mathrm{C}$ at the bottom of the tank and higher efficiency in the collectors loop. Regulation and optimization of water flow rates in the hydraulic loops need to be done and optimal temperature levels have to be reached.

Some faults in the operation of the solar collector's loop controller have been identified. Several changes were made in the solar controller algorithms. Delta on for the solar pump is changed from $12{ }^{\circ} \mathrm{C}$ to $6{ }^{\circ} \mathrm{C}$ and delta off is changed from $6{ }^{\circ} \mathrm{C}$ to $3{ }^{\circ} \mathrm{C}$. This modification allows running a solar loop even if there is a low level of available solar radiation. The temperature limit from the solar collectors to the tank was changed from $65^{\circ} \mathrm{C}$ to $85^{\circ} \mathrm{C}$.

Monitoring and optimization of the system needs to be continued in order to lower temperature levels in the accumulation tank bottom.

\section{CONCLUSIONS}

Current utilization of natural resources in the district heating sector in Latvia is not sustainable and leads to energy dependency from natural gas import. At the same time, solar thermal energy (together with biomass resources) can provide an economically and environmentally justified replacement for natural gas.

It is important not only to replace one type of resource with another which is more environmentally sound. Replacement of natural gas with pellets is considered, as well as an opportunity to use technology (solar collectors) where the resources for heat supply (solar irradiation) are free. By adding the solar thermal energy share in the heat supply system, the use of biomass can be eliminated when solar irradiation is sufficient, therefore saving biomass resources for demand in other sectors or for products with higher value added.

The main benefits of natural gas boiler replacement with a solar combisystem are the use of domestic renewable energy sources and a reduction of energy resource import costs, providing local employment and ensuring a more stable price for SH and DHW services.

The solar combisystem project was implemented for a multi-family building in the city of Sigulda, Latvia. The multifamily building was chosen because it had a more uniform heat load profile with the means for a higher solar share without adding additional heat storage volume.

Monitoring data shows that the combisystem is not working in the most efficient way, real data differs from simulation results, and therefore optimization of the system's performance is needed. Nevertheless, economic analysis shows that the heat energy produced by the combisystem is cheaper compared to natural gas. In order to achieve higher solar thermal energy share, building renovation is needed to be completed and the efficiency of solar collector loop performance needs to be increased.

\section{ACKNOWLEDGEMENT}

The work was supported by the European Economic Area financial Mechanism, Program "Environmental policy and integration of Latvia" and by the European Regional Development Fund from European Commission within the framework of "Central Baltic INTERREG IV A Programme 2007-2013".

\section{REFERENCES}

1. European Solar Thermal Technology Platform. Solar Heating and Cooling for a Sustainable Energy Future in Europe. Brussels : Renewable Energy House, 2007. 123.

2. Guideline for combined solar thermal and wood pellet heating systems. s.1. : Project Sollet, 2006. p. 136.

3. International Energy Agency. Solar Heating and Cooling Programme. Task 26// Objectives. [Online] [Cited: 2 May 2011.] http://www.ieashc.org/task26/objectives.htm.

4. Letz, T., Bales, C. and Perers, B. A new concept for combisystems characterization: The FSC method. s.1. : Solar Energy, 2009. pp. 15401549.

5. Letz, T. Validation and background information on the FSC procedure. France : International Energy Agency, 2002. p. 23. 
6. Kalogirou, S. A. Solar thermal collectors and applications. Progress in Energy and Combustion Science. 2004, Vol. 30, 231-295.

7. Hossain, M. S. et al.. Reviewon solar water heater collector and thermal energy performance of circulating pipe. s.1. : Renewable and Sustainable Energy Reviews, 2011. pp. 3801-3812.

8. Lund, P. D. Sizing and applicability considerations of solar combisystems. s.1. : Solar Energy, 2004. pp. 59-71.

9. Weiss, W. Solar combisystems for a sustainable energy future. s.1. : IEA Solar Heating and Cooling Programme Annual Report 2001, 2002. pp. 10-15.

10. Weiss, W. Solar heating systems status and recent technology developments. Goeteborg, Sweden : ISES Solar World Congress, 2003.

11. Chasapis, D. et al., Monitoring and operational results of a hybrid solarbiomass heating system. s.l. : Renewable Energy, 2008. pp. 1759-1767.

12. Gordon, J. Solar Energy, The State of the Art. London : James \& James (Science Publishers) Ltd, 2001. p. 706. ISBN 1902916239.

13. Duffie, J. A. and Beckman, W. A. Solar Engineering of Thermal Processes 2nd edition. s.1. : Jogn Wiley \& Sons, Inc, 1991. p. 919. ISBN 0-471-51056-4.

14. Rodriguez-Hidalgo, M. C., et al., et al. Flat plate thermal solar collector efficiency: Transient behavior under working conditions. Part I: Model description and experimental validation. s.l. : Applied Thermal Engineering, 2011. pp. 2394-2404.

15. Andersen, E. and Furbo, S. Theoretical variations of the thermal performance of different solar collectors and solar combi systems as function of the varying yearly weather conditions in Denmark. s.1. : Solar Energy, 2009. pp. 552-565.

16. Fiedler, F., et al., et al. Thermal performance of combined solar and pellet heating system. s.1. : Renewable Energy, 2006. pp. 73-88.

17. Central Statistical Bureau of Latvia. Energy statistics. [Online] [Cited: May 20, 2011.]

18. Súri, M., et al., et al. Potential of solar electricity generation in the European Union member states and candidate countries. JRC. [Online] Solar Energy, 2007. [Cited: 27 June 2011.]

http://re.jrc.ec.europa.eu/pvgis/

19. European Commision. Eurostat database. [Online] [Cited: May 25, 2011.]

20. European Solar Thermal Industry Federation. Solar Thermal Markets in Europe, Market Statistics 2010. Brussels : Renewable Energy House.

21. Solar district heating - Sweden, Introduction. [Online] [Cited: 15 June 2011.] http://www.solar-districtheating.eu/se/SDHSweden/Introduction.aspx.

22. Rochas, C. Experimental analysis of solar combisystems. Optimiztion PhD Thesis. Riga, Latvia : Riga Technical University, 2008. p. 123.

23. SIA "Ekodoma". Energy audit report for Kr.Barona Street 2, Sigulda, Latvia. Riga : s.n., 2010.

24. Rubina, M. Siltumapgāde. Problēmas un risinājumi pašvaldību administratīiajās teritorijās. s.1. : Pērse, 2002.

25. Peuser, F. A., Remmers, K. and Schnauss, M. Solar Thermal Systems, Successful Planning and Construction. s.1. : Solarpraxis AG, Germany, in association with James \& James Ltd, UK, 2002. ISBN 3-934595-24-3.

26. Bolonina, A., et al. Compact solar combisystem for an apartment building. Riga : 2010.

27. JSC Latvijas Gāze. Tarifi. [Online] [Cited: 2 July 2011.]

28. International Energy Agency. Statistics. [Online] [Cited: May 25, 2011.]

29. Public Utilities Commission. Publications. Annual Report 2010. [Online] [Cited: June 16, 2011.]

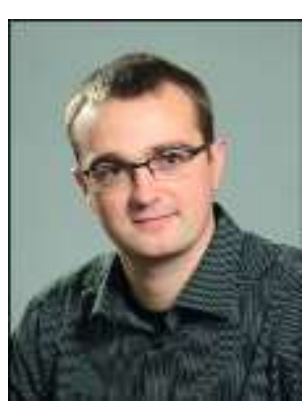

Aivars Zandeckis, M.sc., researcher, Riga Technical University, Institute of Energy Systems and Environment. Since 2005 Aivars Zandeckis is working in Riga Technical university as a head of Environmental monitoring laboratory and since 2010 as a researcher in Institute of Energy Systems and Environment. The main research areas are renewable energy resources and heating technologies. He has participated in 18 local and international scientific projects related to renewable energy use and efficiency improvement in residential, tertiary and commercial sectors. Aivars is an author of 19 scientific publications and coauthor of one monograph and two local patents. He has master Diploma in Environmental science. Master thesis "Research of pellet combustion efficiency" was defended in RTU in 2008.

Address: Kronvalda blvd. 1, LV-1010, Riga, Latvia

Phone: +371 67089908

E-mail: aivars.zandeckis@rtu.lv

Lelde Timma, B.sc, Master student, assistant in scientific work

Riga Technical University

Institute of Energy Systems and Environment

E-mail: lelde.timma@rtu.lv

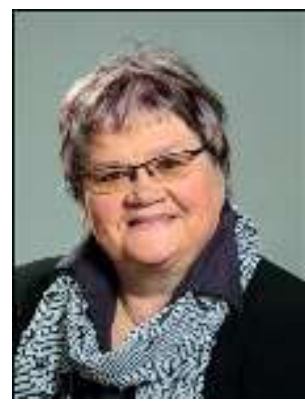

Dagnija Blumberga, Dr.hab.sc.ing., professor, Riga Technical University, Institute of Energy Systems and Environment. Professor Dagnija Blumberga has been part of academic staff of Faculty of Electrical and Power Engineering, Riga Technical University since 1976 and director of Institute of Energy Systems and Environment since 1999. The main research area is renewable energy resources. She has participated in different local and international projects related to energy and environment as well as is author of more than 200 publications and 14 books. She has Thermal Engineer Diploma (1970) and two steps doctoral degree diploma Diploma. PhD thesis "Research of Heat and Mass Transfer in Gas Condensing Unit" was defended in Lithuanian Energy Institute, Kaunas (1988). Doctor Habilitus Thesis "Analysis of Energy Efficiency from Environmental, Economical and Management Aspects" was prepared in Royal Institute of Technology (KTH) Stockholm (1995) and was defended in Riga Technical University (1996).

E-mail: dagnija.blumberga@ rtu.lv

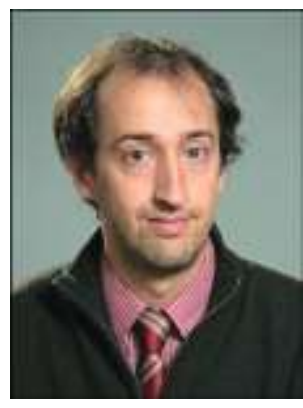

Claudio Rochas, Dr. sc. ing, associate professor, Riga Technical University, Institute of Energy systems and Environment. In 2000 Claudio Rochas acquired Masters degree at Polytechnic University of Turin. In 2008. he acquired a PHD degree in Environmental Engineering at Riga Technical University. PHD thesis "Experimental analysis of solar combisystems. Optimization". Claudio Rochas has a professional experience of almost 10 years in the energy and environmental field within RTU (since 2003). As researcher in Riga Technical University, Institute of Energy systems and Environment he has been involved in more than 10 energy and environmental research projects in particular focusing on solar energy, cogeneration and dispersed energy solutions Mr. Rochas has more than 30 publications.

E-mail: claudio.rochas@rtu.lv

Aivars Žandeckis, Lelde Timma, Dagnija Blumberga, Claudio Rochas. Saules siltuma izmantošanas iespējas daudzdzīvokḷu ēkās.

Energètikas sektros spēlē nozīmīgu lomu ikvienā valstī. Ilgtspējīga energétikas politika nodrošina stabilu ekonomisko izaugsmi un pasargā vietējo tirgu no straujām enerǵijas cenas izmaiṇām. Eiropas Savienība (ES) ir noteikusi, ka līdz 2030. gadam ES-25 valstīm 20\% no siltumenerğijas pieprasijjuma jānodrošina, izmantojot saules enerǵiju. Lai sasniegtu šo mērḳi, Eiropas līmenī tiek îstenoti dažādi izpētes un att̄̄stības projekti.

Pētījums ietver informāciju par saules siltuma tehnolog̣iju tirgus attīstību Latvijā. Saules enerǵijas potenciāls un tirgus izaugsme Latvijā tiek salīdzināta ar citām valstīm, kur pieejamais saules radiācijas daudzums ir ekvivalents Latvijas klimatiskajiem apstākḷiem. Ar Eiropas Savien̄̄bas finansiālo atbalstu tika īstenots Rīgas Tehniskās universitātes Vides aizsardzības un siltuma sistēmu institūta un trīs Latvijas uzṇēmumu sadarbības projekts „Kompaktais saules un granulu modulis". Projekta ietvaros tika izveidota kompakta katlu mājā, kurā tika uzstādīta saules un granulu kombisistēma. Saules un granulu kombisistēma nodrošina apkuri un karstā ūdens sagatavošanu vienai daudzdzīvokḷu ēkai Siguldā. Publikācijā tiek iekḷauts saules un granulu kombisistēmas pilotprojekta apraksts, definēti galvenie sistēmas raksturlielumi un analizēti pirmo piecu mēnešu darbības rezultāti. Tiek salīdzināti dažādi siltumapgādes sistēmu scenāriji renovētai un nerenovētai ēkai ņemot vērā izdevumus resursu iegādei. 